\title{
Values of Local Wisdom in the Traditional of Tepung Tawar
}

\author{
Tri Utami ${ }^{1 *}$, Hasmika Hasmika ${ }^{2}$ \\ ${ }^{1}$ Universitas Negeri Yogyakarta, Yogyakarta \\ ${ }^{2}$ Universitas Pendidikan Indonesia \\ *Corresponding author. Email: tri327pasca.2019@student.uny.ac.id
}

\begin{abstract}
The Indonesian nation is a nation that has a diversity of religions, ethnicities, races, cultures, customs and traditions that are spread throughout Indonesia. Indonesia's diversity is a wealth as well as a blessing that must be maintained and preserved for the Indonesian people. The tepung tawar tradition is a tradition carried out by the Sambas Malay community, especially in the Semparuk sub-district, Sambas district. Many people know and even follow this tradition, but are not fully aware of the values of local wisdom contained in it. Therefore, this study aims to determine the implementation and values of local wisdom in the tradition of tepung tawar in Semparuk sub-district, Sambas district. This research uses descriptive research with a qualitative approach. The data analysis technique used is inductive which consists of three activities, namely data reduction, data presentation, and conclusion drawing. The results showed that the implementation of the tepung tawar tradition went through the preparation stage, implementation stage, and postimplementation stage. The values of local wisdom in the tepung tawar tradition are the value of mutual cooperation, religious value, and the value of unity. Local wisdom shows the local cultural identity of the community and can then be developed for the welfare of the community.
\end{abstract}

Keywords: Local Wisdom, Tepung Tawar Traditio, ValueS.

\section{INTRODUCTION}

The Indonesian country is a country that has a diversity of religions, ethnicities, races, cultures, customs and traditions which are spread at some point of the territory of Indonesia. Indonesia's diversity is a wealth as well as a blessing that must be maintained and preserved for the Indonesian people. Every tribe basically has extraordinary customs, traditions, customs, and cultures [1]. The Indonesian nation, with its various styles, forms and characteristics of regional culture which has various potentials for the development of its cultural values is a source of national wealth [2]. The diversity of race, ethnicity, language, culture, and religion is a characteristic and advantage of the Indonesian nation that distinguishes it from other nations [3]. Research conducted by Alunaza states that the cultural diversity possessed by the Indonesian state certainly has many positive sides, one of which is that Indonesia can be known in the international community through its very rich and diverse culture [4]. Therefore, with the diversity that Indonesia has, it can be a strength for the Indonesian nation. Research performed by Basyari states that the values contained in a subculture can maintain social integrity and cultural protection as a manifestation of the social and cultural identity of the network [5]. Therefore, the diversity of cultures and traditions that exist in Indonesia which has moral values, ethics, and norms should be maintained and preserved. Awareness to maintain, maintain, and develop cultural values reflects the noble values and wealth of the Indonesian nation as a form of concern for the sustainability of the nation's original culture.

Value is an idea that is learned/implanted from an early age [6]. value is an concept, a idea, approximately some thing that is considered vital in existence [7]. Darmadi said that cost is some thing that has exact fee according to the standards of good judgment (right-wrong), aesthetics (exact-bad), ethics (honest/honest-unfair), religion ( $\sin$ and haram-halal) as well as being a reference and primarily based on notion systems self and existence [8]. Value is also a thought that a person has on something that is considered important so that it can change someone's behavior which is good/bad. Values are abstract and indicate the quality of something that has good intentions and benefits everyone. Value is usually placed on something that is explicit and implicit in facts, concepts, or theories so that it can be functionally meaningful [9]. Values are beliefs that emerge as the basis for someone or organization of humans to select their moves or choose something this is significant for his or her lives [10]. Adisusilo explained that values will always be related to 
goodness, virtue, and nobility and will become something that is appreciated and upheld and pursued by someone so that he feels like a real human being [11]. In line with this, Idawati \& Setiawan explain that value is something that gives meaning to life, which provides a reference, starting point and purpose of life [12]. Therefore, the value becomes something that is upheld, which can color and animate one's actions.

The values contained in a tradition can be a guide for behaving and interacting in society so as to provide strength in managing or preserving culture. The attitudes and behavior of the people who are traditional, because they are based on values that are believed to be true, are a manifestation of local wisdom. As stated by Syarifuddin that values can distinguish between humans in society and other creatures, because values can be used as a reference to achieve a higher quality life [13]. Sepinggan Village is one of the areas in West Kalimantan Province which has cultural arts and customs that are still thick, original, and well preserved. art, culture and customs, one of which is the tradition of tepung tawar. However, in the implementation of the tepung tawar tradition, most people who do it do not understand the meanings of what local wisdom is contained in it, they just participate in its implementation without knowing the meanings of the local wisdom.

The tradition of tepung tawar as local wisdom that has local know-how values that should be regarded and preserved. local wisdom is identified as values and practices adopted by means of the network [14]. Kristiyanto defined that nearby expertise is a conventional know-how that will become a reference for conduct and has been finished from generation to era in meeting the wishes and demanding situations in the life of a society [15]. Local wisdom features and is significant in society both for preserving natural and human sources, customs and subculture, in addition to for the lifestyles of the nation and country. Local awareness is a noble cost that can be implemented inside the implementation of network existence to defend and manipulate the environment. Local wisdom involves patterns of relationships among human beings and God, humans and fellow human beings, and human beings and their bodily environment [16].

Local wisdom is vital to stay with the college and engage with all rookies [17]. Local wisdom is carefully related to a kingdom as Wibowo asserts that local wisdom is the cultural identification or persona of a nation that reasons the country with a view to take in, and be capable of manage the tradition that comes from the outside of the kingdom into its own character and potential [18]. Of course, to absorb the culture so that it becomes a character and behavior adapted to the personality and outlook on life of the Indonesian people. Forms of neighborhood awareness are spiritual concord inside the shape of social practices based on expertise from way of life whilst varieties of nearby information in society can be inside the shape of tradition (values, norms, ethics, beliefs, customs, commonplace regulation and special policies) [19]. According to Sumardjoko, local wisdom is the values that live in the community, which are believed to be true and become a reference in the daily behavior of the local community [20]. The shape of local wisdom in society can be inside the shape of a understanding device, fee system, social, and way of life. This is contemplated inside the management of the surroundings, customs, and cultural artifacts which includes assets guidelines, materials and architecture of houses, styles of clothing, furnishings, and ceremonies [21]. The traits of local wisdom in step with Wagiran are (1) local wisdom looks easy, but is frequently complex, comprehensive, and various; (2) due to the fact it's miles tailored to neighborhood, cultural, and environmental conditions; (3) dynamic and bendy; (4) it is tailored to the desires of the area people; (five) this is adjusted to the nice and amount of to be had assets; and (6) it copes properly with change [22].

Based totally on the rationale that has been given, researchers are inquisitive about inspecting the values of neighborhood wisdom contained inside the subculture of tepung tawar in Sepinggan Village, Semparuk District, Sambas Regency, West Kalimantan. The reason of this look at turned into to determine the implementation of the tepung tawar culture inside the village of Sepinggan, Semparuk sub-district, Sambas district, West Kalimantan and to find out the values of neighborhood knowledge in the obvious flour tradition.

\section{LITERATURE REVIEW}

\subsection{The Study of Value}

Value is an idea that is learned/instilled early on [23]. Value is also a thought that a person has on something that is considered important so that it can change someone's behavior which is good/bad. Value is something in the form of abstract, which has value and is characterized by something whose characteristics can be seen from a person's behavior, which has a relationship with facts, actions, norms, morals, and beliefs [24]. In line with this, Muhmidayeli explained that value is a picture of something beautiful, enchanting, amazing, which makes us happy and happy and is something that makes someone want to have it [25]. In addition, Khuriyah, Utaya \& Sapto explained that value is something that gives meaning to life, guidance, starting point and purpose of life [26].

Values become guidelines that are believed by a person in living his life. Values are ideals that come to be the idea for a person or group of human beings to select their movements or decide some thing significant for his or her lives [27]. Values will always be related to goodness, virtue, and nobility and will be something that 
is appreciated and upheld and pursued by someone so that he feels like a real human being. Values will give meaning to life, which provide a reference, starting point and purpose of life. Therefore, the value becomes something that is upheld, which can color and animate one's actions.

\subsection{Study of Local Wisdom}

Local wisdom is one form of regional superiority [28]. Local wisdom is a culture or tradition that is produced through the process of human thought to adjust its existence in the natural environment which can be realized in a real work [29]. In fashionable, local understanding emerges thru inner strategies and lasts a long term which is the end result of interplay between humans and their environment. This lengthy evolutionary manner will result in the emergence of a value system that crystallizes within the form of standard regulation, beliefs and nearby culture. consequently, in essence local information is a norm adopted in society that is trusted and becomes a reference in normal lifestyles [30].

Saihu \& Mailana said that nearby know-how is an attempt made through people by means of using their minds to behave and behave towards an item or event that occurs in a sure space [31]. local wisdom is primary expertise obtained from living in stability with nature, this is associated with tradition in society that is gathered and inherited [32]. neighborhood knowledge in step with Alfian is defined as a view of existence and expertise and existence techniques within the shape of activities finished by using neighborhood groups in meeting their desires [33].

Local wisdom is recognized as values and practices adopted by the community [34]. Kristiyanto defined that nearby understanding is a traditional expertise that turns into a reference for behavior and has been finished from generation to generation in meeting the desires and challenges in the life of a society [35]. nearby awareness features and is meaningful in society each for retaining natural and human sources, customs and way of life, as well as for the lifestyles of the country and kingdom. neighborhood knowledge is a noble cost that can be carried out within the implementation of community life to defend and manage the surroundings. Furthermore, the local wisdom of the Indonesian people reflects the relationship between God, humans, and the universe [36]. Eko \& Putranto revealed that neighborhood information has its very own depth and splendor in revealing the fact of relationships consisting of the connection with God or what's known as the idea of the Almighty, relationships with fellow human beings and the way to live together [36].

Local wisdom can be seen from two perspectives according to Lawrence, namely: (1) extreme acculturation, namely showing imitation forms of a culture without any process of cultural evolution and ultimately destroying traditional cultural forms; (2) acculturation that is not extreme, namely acculturation that still leaves and shows local genius [37]. Namely, the existence of traditional elements or characteristics that are able to survive and even have the ability to accommodate cultural elements from outside and integrate them into the original culture.

\subsection{The Study of the Tradition of Tepung Tawar}

Society is always present with various values, culture, customs and traditions in it [38]. Therefore, society and culture are reciprocal. There are many forms of culture, customs, and traditions that are embraced by every community group in Indonesia, even within the same ethnic group there will be differences in traditions and culture. Tradition is a hereditary custom that comes from ancestors that is still carried out in the community [39]. Tradition can be interpreted as an activity that has been carried out for a long term and is part of the life of a community group. Tradition contains ideas, wisdom, knowledge, skills that are preserved from generation to generation that are continuous with the past [40]. Tradition is the spirit of a culture, and with a cultural system the tradition will be strong [41]. Traditions or cultures that exist in Indonesia are born from ancestors with diverse histories and beliefs and feature unique cultural values in each place [42]. Tradition has a precise goal to achieve through virtue, and supernatural goodness becomes the true measure, and tradition is an effort to fight individual arbitrariness [43].

Tepung tawar is a procession and symbolic (artifact) passed down from predecessors to the next generation until now. The procession of Tepung tawar is a culture that is the result of human work, initiative, and taste [44]. The tepung tawar tradition is one that uses biodiversity for various purposes, traditional medicine, planting cycle rituals, housewarming rituals, and other transitional rituals [45]. The tradition of tepung tawar is a symbol of seeking safety for what has been owned or cultivated. Safety of possessions such as the birth of a child so as not to get sick, or safety from being disturbed by spirits that are often experienced by children when they are babies [46]. Socially, tepung tawar occurs with social interaction in the community through figures who have influence and important roles that are considered respected in the Pontianak Malay community. [47]. Based on the explanation that has been conveyed, the tradition of tepung tawar intended in this study is the tradition of tepung tawar done the Sambas Malay network inside the village of Sepinggan on the baby tepung tawar occasion.

\section{METHOD}

The technique in this research is qualitative by means of using descriptive studies kind. The studies was conducted in Sepinggan Village, Semparuk District, 
Sambas Regency, West Kalimantan. facts have been collected via interview, remark, and documentation techniques. The validity of the records changed into examined by using the usage of triangulation method. Records analysis is inductive with tiers of statistics reduction, information show, conclusion and verification.

\section{RESULT AND DISCUSSION}

\subsection{Tepung Tawar Tradition in Sepinggan Village}

The tradition of tepung tawar has its own ways with stages such as sprinkling water on people or objects and so on. The implementation of a nation's traditional traditions will definitely go through the processes in it. Be it the preparation process, the implementation process, to the post-implementation process. The process is incorporated into a procedure according to the relevant custom, in this case is the procedure for implementing the tepung tawar custom in the village of Sepinggan.

Based on the research that has been done, the equipment needed in the process of implementing the tepung tawar tradition of Sepinggan Gelik Village include: (1) rice flour; (2) air tolak bala; (3) leaf juang; (4) intibar; (5) kebali/ gembali; (6) leaf ribu-ribu; (7) ayaman selimpat; (8) coconut. As for how to present the traditional plain flour equipment, among others: (1) Rice flour that has been mashed is put into a place that has been filled with tolak balla water, usually the place is in the form of a large bowl like a basin. (2) Mix and stir the rice flour and tolak balla water until evenly distributed, then collect the fighting leaves, Intibar leaves, and Kebali leaves into a single bundle. (3) Put the bundles of the leaves in a bowl containing rice flour and tolak balla water that comes with the coconut that has been opened on top.

After all the traditional white flour equipment is ready, then before the event begins, first perform the bepapas ritual, this is what is meant by tepung tawar. This tepung tawar tradition is a traditional ritual that is carried out based on hereditary customs that were previously carried out by the Malay traditional leaders of Sepinggan Village. The order of the procession of the tepung tawar tradition is as follows:

1. Parents and babies who will be papas are presented first in front of the village midwife.

2. The village midwife began to prepare traditional tepung tawar utensils and then read prayers for parents and babies.

3. The juang leaves, Intibar leaves and rivbu-ribu leaves that have been tied are dipped in rice flour which has been mixed with water tolak balla which is put into a special place to store rice flour.

4. The village midwife will start doing bepapas by gently tapping the tied leaves towards the head, right shoulder and left shoulder, then hands and feet, this treatment is for parents and their babies.
5. After the child and mother bepapas by the village midwife, the village midwife was passed by the mother. After doing the tepung tawar traditional, they usually go directly to the next event, which is baby hair clipping which is presented by invited guests who are in the assembly.

6. Furthermore, the process of cutting the baby's hair is carried out by traditional leaders and religious leaders, usually more than seven people. However, before cutting the hair of the traditional leaders and other invited guests, they read the remembrance of the dzikir barjanji/nyerakal. The reading of the book of Barzanji or called nyarakal carried out by the Malay community of the village of Sepinggan Gelik is usually accompanied by various musical instruments such as drums and rumba.

7. After the haircut, the baby and the parents returned to the house, and the invited guests continued to recite the sarakalan until it was finished.

\subsection{The Values of Local Wisdom of the Tepung Tawar Tradition}

\subsubsection{Religius Value}

Religious values are the basis of the formation of religious culture, because without the cultivation of religious values, religious culture will not be formed [48]. Religious values come from religion and are able to penetrate into the intimacy of the soul. Religious values need to be instilled in a person. With the existence of religious values or religious values will guide humans in everyday life [49]. Religion is not only concerned with the external aspects of life but also involves the totality of the human person in its integration into the oneness of God. Religious values aim to educate people so that they are better according to religious guidance and always remember God [50].

In essence, the tradition of tepung tawar is to ask for salvation from Allah SWT. This tradition is an expression of gratitude to God Almighty for having been blessed with blessings and asking to always be given health and safety. The religious values contained in the white flour tradition are reflected in a series of events that use Islamic prayers. The prayers that are said are praising Allah SWT, praising Prophet Muhammad SAW, praying for religious safety, asking for health, knowledge and blessings, receiving mercy and forgiveness from Allah SWT in this world and the hereafter. It is clear that there is an acculturation of Islam with local wisdom found in the tepung tawar tradition. Acculturation of Islam with local culture is a shape of keeping neighborhood culture [51].

\subsubsection{The value of mutual cooperation}

For the people of Indonesia, mutual cooperation is not a foreign term, even the majority of people in Indonesia feel familiar with the term. Mutual cooperation became a popular term during the Soekarno government or the Old Order period, where Sukarno introduced the idea of gotong 
royong as an Indonesian-style togetherness value that must be a spirit in the life of society and the state. Even during Soekarno's time there was a government cabinet called the Gotong Royong Cabinet. Mutual cooperation is widely recognized as one of the values that characterizes the individual of the Indonesian kingdom so that within the philosophy of the Indonesian country, namely Pancasila, among others in the values of humanity, unity, deliberation, and social justice [52].

According to Soekanto, mutual cooperation is a traditional cooperation with feelings, sharing and mutual need as community sentiments [53]. Gotong royong is a dynamic ideology, which describes a joint attempt, a charity, a piece or a joint paintings, a warfare to assist every different [54]. The fee of gotong royong may be used positively in life to mobilize social cohesion in order that the Indonesian country is capable of face the demanding situations of changing instances, globalization, and various things that threaten humans's lives such as natural screw ups, social and political conflicts. The importance of maintaining the price of mutual cooperation inside the tepung tawar way of life, one in every of that is to preserve the traditions/customs of the network, due to the fact with the lifestyles of gotong royong many benefits and blessings are felt, which include paintings will become simpler due to cooperation and mutual help, can reinforce and fortify family members between residents, and unite residents from the young and old organizations in each interest. The procession of the tepung tawar tradition will not run smoothly if the people just walk alone. Gotong royong aims to make it easier to complete a job or a burden that is obtained [55]. Gotong royong is very dominant in the plain flour tradition because at the time of implementation, good mutual cooperation is needed between the family holding the event and the surrounding community. Gotong royong is a dynamic ideology, which describes a joint attempt, a charity, a piece or a joint paintings, a warfare to assist as a Malay community, the cultivation of gotong royong in the implementation of the white flour tradition requires a strong sense of solidarity.

\subsubsection{Unity Value}

Throughout the history of the independence of the Indonesian nation, it cannot be separated from the role of society. The role of society, especially young citizens today, is to inculcate Pancasila values in life. Pancasila is not just an ideology, but needs to be understood as the moral basis of the Indonesian nation. The moral basis which is the values and is indispensable for the civilization of the Indonesian nation, particularly the cost of divinity, the fee of humanity, the fee of solidarity, the price of deliberation, and the fee of justice [56]. The value of unity as a concept of skill in the Indonesian context means from understanding its substantial value as a view of the nation's life, namely the value of unity as a concept that contains noble goodness which must be applied by the new generation of this nation [57].
Tradition is usually intended to refer to a norm, value and custom that has blended for a long time until now is still accepted, followed and even maintained by certain communities [58]. As has been done by the people of the village of Sepinggan who are still carrying out the tradition of tepung tawar as a form of embodiment of the preservation of noble culture. One of the values contained in this tepung tawar tradition is the value of unity. The inculcation of the values of unity is an important part of the existence of the country and nation, not only to respect each other's differences, but the realization of its implementation fosters a sense of unity and unity in the community and creates a peaceful and peaceful life. The value of unity implies that the state is the embodiment of monodual human nature, namely as individual beings and social beings. This is very relevant to the heterogeneous condition of society, the unity of all religions, groups, races, and ethnicities is a demand for mutual care and respect for the integrity of the Republic of Indonesia.

\section{CONCLUSION}

The implementation of the tepung tawar tradition in the village of Sepinggan as a form of cultural preservation. The tradition of tepung tawar deserves to be carried out in today's modern era. The tradition of tepung tawar has values that are still according with the situations of the network, specially the village of Sepinggan. The values of local wisdom within the tepung tawar subculture consist of spiritual values, mutual cooperation values, and the value of unity.

\section{REFERENCES}

[1] Ridwan, M., \& Wahdian, A. (2017). Structure, function and value the tradition of oral literature in sumenep madura. Journal of Intensive Studies on Langguage, Literature, Art, And Cultur. 1(1). 252273.

Doi: http://dx.doi.org/10.17977/um006v1i12017p252.

[2] Susilowati, E., \& Masruroh, N. N. (2018). Merawat kebhinekaan menjaga keindonesiaan: belajar dari nilai keberagaman dan kebersatuan masyarakat pulau. Jurnal Sejarah Citra Lekha. 3(1). 13-19. https://doi.org/10.14710/jscl.v3i1.17856.

[3] Alunaza, H. (2014). Analisa diplomasi budaya Indonesia melalui tari saman gayo dalam mengukuhkan identitas nasional bangsa. Jurnal Hubungan Internasional. 1(4). 88-96. ISSN: 25033883.

[4] Basyari, W. I. H. (2014). Nilai-Nilai Kearifan Lokal (Local Wisdom) Tradisi Mamitu Pada Masyarakat Cerebon). Jurnal Edunomic. 2(1). 47-56.

[5] Rahman, A. M. (2019). Nilai, norma dan keyakinan remaja dalam menyebarkan informasi sehari-hari di media sosial. Jurnal Ilmu Perpustakaan dan Informasi. 4(1). 68-83. Doi: http://dx.doi.org/10.30829/jipi.v4il.4110. 
[6] Nawawi, A. (2011). Pentingnya pendidikan nilai moral bagi generasi penerus. Jurnal Pemikiran Alternatif Kependidikan. 16(2). 119-133. Doi: 10.24090/insania.v16i2.1582.

[7] Darmadi, H. (2009). Dasar konsep pendidikan moral. Bandung: Alfabeta.

[8] Faridah., \& Sutiyono. (2018). The meaning of symbol and moral values in equipment of mappaccing tradition of Bugis race. Advances in Social Science, Education and Humanities Research. 327. 197-201. Doi: https://doi.org/102991/icaae-18.2019.38.

[9] Turistiati, T. A. (2019). Islamic values in mottainai philosophy and osagari tradition in Japan. Jurnal Kajian Islam dan Budaya. 17(2). 214-225. Doi: 10.24090/IBDA.V17i2.3244.

[10] Adisusilo, S. (2012). Pembelajaran nilai-karakter. Jakarta: Rajagrafindo Perseda.

[11] Idawati, \& Setiwan, J. (2016). Nilai-nilai pada tradisi Nandong di desa kampung baru inuman kecamatan inuman kabupaten kuantan singing provinsi riau. Jurnal Koba. 3(1). 89-99.

[12] Syarifudin, D. (2016). Nilai wisata budaya seni pertunjukan angklung udjo kota bandung, jawa barat, indonesia. Jurnal Manajemen Resort dan Leisure. 13(2). Doi: https://doi.org/10.17509/jurel.vl3i2.4979.

[13] Kusumasari, B., \& Alam, Q. (2012). Local wisdombased disaster recovery model in indonesia. Dasaster Prevention and Management. 21(3). 351-369. Doi: http://dx.doi.org/10.1108/09653561211234525.

[14] Kristiyanto, N. E. (2017). Kedudukan kearifan lokal dan peranan masyarakat dalam penataan ruang di daerah. Jurnal Media Pembinaan Hukum Nasional. 6(2). 159-177. ISSN 2089-9009.

[15] Ridwan, N. A. (2017). Landasan keilmuan kearifan lokal. Jurnal Studi Islam dan Budaya. 5(1).27-38.

[16] Chusorn., Pornpimon., \& Ariratana., et al. (2014). Strategy challenges the local wisdom applications sustainability in schools. Procedia-Social and Behavioral Sciences. 112. 626-634. Doi: 10.1016/j.sbspro.2014.01.1210.

[17] Wibowo, A. (2015). Pendidikan karakter berbasis kearifan lokal di sekolah. Yogyakarta: Pustaka Belajar.

[18] Hariyanto. (2014). Kearifan lokal pendukung kerukunan paradigma pada komunitas tengger Malang di Jwa Timur. Jurnal Analisis. 21(2). 201413.

[19] Sumardjoko, B. (2018). Model of civic education based on the local wisdom for revitalizing values of Pancasila. Cakrawala Pendidikan. 2(29). Doi: 10.21831/cp.v37i2.18037.

[20] Maryani, E., \& Yani, A. (2014). Kearifan masyarakat sebagai sumber belajar ips dan keunggulan karakter bangsa, makalah pada konvensi pendidikan nasional IPS (KONASPIPSI). Bandung.

[21] Wagiran. (2012). Pengembangan karakter berbasis kearifan lokal hamemayu hayuin bawana (idenifikasi nilai-nilai karakter berbasis budaya). Jurnal Pendidikan Karakter. II(3). 329-339 Doi: https://doi.org/10.21831/jpk.v0i3.1249.

[22] Rahman, A. M. (2019). Nilai, norma dan keyakinan remaja dalam menyebarkan informasi sehari-hari di media sosial. Jurnal Ilmu Perpustakaan dan Informasi. 4(1). 68-83. Doi: http://dx.doi.org/10.30829/jipi.v4il.4110.

[23] Frimayanti, I. A. (2017). Implementasi pendidikan nilai dalam pendidikan agama Islam. Jurnal Pendidikan Islam. 8(II).227-247. E-ISSN: 25282476.

[24] Muhmidayeli. (2013). Filsafat pendidikan. Bandung: Refika Aditama.

[25] Khuriyah, L., Utaya, S., \& Sapto, A. (2017). The relevance of erau traditiona values toward character building values. Asian Social Science. 13(6). 102112. Doi: https://doi.org/105539/ass.v13n6p102.

[26] Turistiati, T. A. (2019). Islamic values in mottainai philosophy and osagari tradition in Japan. Jurnal Kajian Islam dan Budaya. 17(2). 214-225. Doi: 10.24090/IBDA.V17i2.3244.

[27] Kurniawati, A. A., Wahyuni, S., \& Putra, A. D. P. (2017). Utilizing of comic and jember's local wisdom as integrated science learning materials. International Journal of Social Science and Humanity. 7(1). 47-50. Doi: 10.18178/ijssh.2017.7.1.793.

[28] Dahliani., Soemarno, I., \& Setijanti, P. (2015). Local wisdom in bult environment in globalization era. International Journal of Education and Research. 3(6). 157-166. ISSN 2411-5681.

[29] Vitanyi, I. (1992). Traditional and modernity. The Journal of New Paradigma Research. 34(3-4). 253255.

Doi: https://doi.org/10.1080/02604027.1992.9972312.

[30] Saihu., \& Mailna, A. (2019). Teori pendidikan behavioristik pembentukan karakter masyarakat muslim dalam tradisi ngejot di Bali. Jurnal Pendidikan Islam. 8(2).163-176. Doi: 10.32832/tadibunav812.2233.

[31] Mungmachon, R. M. (2012). Knowledge and local wisdom: community treasure. International Journal of Humanities and Social Science. 2(13). 174-181.

[32]Alfian, M. (2013). Potensi kearifan lokal dalam pembentukan jati diri dan karakter bangsa. Prosiding the 5 thn ICSSSIS Ethnicity and Globalization. Yogyakarta. 13-14 Juni 2013.

[33] Kusumasari, B., \& Alam, Q. (2012). Local wisdombased disaster recovery model in indonesia. Dasaster 
Prevention and Management. 21(3). 351-369. Doi: http://dx.doi.org/10.1108/09653561211234525.

[34] Kristiyanto, N. E. (2017). Kedudukan kearifan lokal dan peranan masyarakat dalam penataan ruang di daerah. Jurnal Media Pembinaan Hukum Nasional. 6(2). 159-177. ISSN 2089-9009.

[35] Hemafitria, Budimansyah. D., \& Winataputra, U. (2018). Strengthening nation's character though saprahan local wisdom as civic culture of malay sambas society in Kalimantan Barat. Advances In Social Science, Education And Humanities Research. 251. 410-413. https://doi.org/102991/acec$\underline{18.2018 .93}$.

[36] Eko, S. B., \& Putranto, H. (2019). The role of intercultural competence and local wisdom in building intercultural and inter-religious tolerance. Journal Of Intercultural Communication Research. 48(4). 341-369. Doi: https://doi.org/10.1080/17475759.2019.1639535.

[37] Lawrence, D. R. (2019). In search og greater india HG ouaritch wales: pioneer archaeologist, art historian and war correspondent. Australia: Australia National University.

[38] Atem. Nilai-nilai kearifan lokal dalam budaya pantang larang suku Melayu Sambas. Jurnal Ilmu Ushuluddin. 16(1).11-20. 2017.

[39] Muhakamurrohman, A. (2014). Pesantren: santri, kiai, dan tradisi. Jurnal Kebudayaan Islam. 12(2). 109-118.

[40] Ferreiro, F. D. M., et al. (2019). Traditional and innovation: beetween dynamics and development. African Journal of Science. 11(5). 533-542. Doi: https://doi.org/10.1080/20421338.2018.1558743.

[41] Hiroyuki, A., Juliawan, N. I., \& Sudarsana, K, K. I. (2018). Internalization values of character education towards the terun-daha in the medi-median tradition. International Journal of Hindu Science and Religious Studies. 2(2). 232-238.

[42] Ati, S. (2018). Oral tradition of kololi kie as a cultural learning resourch for the island ternate community. ISLLAC: Journal of Antensive Studies on Language Literature, Art, and Culture. 2(1). 71-74. Doi: http://dx.doi.org/10.17977/um006v2i12018p071.

[43] Smith, P. A. (2014). Against traditional to liberate tradition. Journal of The Theoretical Humanities. 19(2). 145-159. Doi: https://doi.org/10.1080/0969725X.2014.950870.

[44]Hamidah. (2014). Pengajaran moral dalam budaya tepung tawar Melayu Sumatra Utara. Forum Pedagogik. 43-58. Desember 2014.

[45]Royyani, F. M. (2014). Tepung tawar: keragaman hayati dan jejak budaya di pegunungan Meratus. Jurnal Biologi Indonesia. 10(2). 213-219. Juni 2014.
[46]Hemafitria. (2019). Nilai karakter berbasis kearifan lokal tradisi tepung tawar pada etnis Melayu Sambas. Jurnal Pendidikan Kewarganegaraan. 3(2). 121-132. Desember 2019.2 Doi: http://dx.doi.org/10.31571/pkn.v3i2.1435

[47] Ramadhan, D., \& Wahab. Relevansi kearifan lokal tepung tawar dalam pembelajaran agama islam (studi pada masyarakat Melayu Pontianak). Jurnal Tarbiyah: Jurnal ilmiah Kependidikan. 8(1). 53-62. Juni 2019.

[48] Fathurrohman, M. (2016). Pengembangan budaya religius dalam meningkatkan mutu pendidikan. TA'ALLUM. 4(1). 19-42.

[49] Suryani, I., Rahariyoso, D., \& Maulana, Y. R. (2019). Values Contained in the biduk oral traditional the society of the jernih village. Jurnal Ilmu Humaniora. 3(1). E-ISSN: 2597-7229

[50]Edi, B. S. (2017). Nilai-nilai pendidikan dalam dongeng tayangan televisi, dalam Mlangun. Jurnal Ilmiah Kebahasaan dan Sastra. 14(2).

[51] Rahmaniar, S. F., Suyitno.,\& Supana, et al. (2020). Keselarasan kearifan lokal dengan nilai keIslaman pada tradisi labuhan gunung kombang di Kabupaten Malang. Jurnal SmaRT studi Masyarakat, Religi, dan Tradisi. 6(1). 113-125. Doi: https://doi.org/10.18784/smart.v6i1.805.

[52] Subagyo. (2012). Pengembangan nilai dan tradisi gotong royong dalam bingkai konservasi nilai budaya. Jurnal Sejarah. 1 (1). 61-68. Doi: https://doi.org/10.15294/ijc.v1.2065.

[53] Soekanto, S. (2013). Sosiologi suatu pengantar. Jakarta. Rajawali Press.

[54] Effendi. N. T. (2013). Budaya gotong-royong masyarakat dalam perubahan sosial saat ini. Jurnal Pemikiran Sosiologi. 2(1).164-165.

[55] Harvina. (2020). Nilai-nilai gotong royong dalam tradisi sihali aek pada masyarakat Toba di Humbang Hasudutan. Jurnal Hasil Penelitian Ilmu Sosial dan Humaniora. 6(2). 314-327. Doi: https://doi.org/1036869/pjhpish.v6i2.147.

[56] Danusaubroto, S. (2013). Membumikan empat pilar menjaga eksistensi bangsa. Jurnal kementerian sekretariat negara republik indonesia negarawan. 28. 18-19.

[57] Hanafi. (2018). Hakekat nilai persatuan dalam konteks Indonesia (sebuah tinjauan kontekstual positif sila ketiga Pancasila). Jurnal Ilmiah Pendidikan Pancasila dan Kewarganegaraan. 3(1). 56-63. ISSN: 2528-0767.

[58] Sari, R. M. P., \& Priyanto, S. A. (2019). Silaturahmi sebagai bentuk utama dalam kepedulian sosial pada tradisi Weh-Wehan di Kaliwungu. Indonesian Journal of Conservation. 8(1). 41-50. ISSN: 22529195. 